\title{
MODELING NATIONAL
}

INNOVATION SYSTEMS OF

\section{EU COUNTRIES USING PARTIAL}

LEAST SQUARES STRUCTURAL

\section{EQUATION MODELING (PLS-SEM)}

\author{
Hacettepe University \\ Journal of Economics \\ and Administrative \\ Sciences \\ Vol. 35, Issue 3, 2017 \\ pp. 19-42
}

\author{
Süleyman ÇAKIR \\ Asst.Prof.Dr. Recep Tayyip Erdoğan \\ University, \\ Faculty of Economics and Administrative \\ Sciences \\ Department of Business Administration \\ suleyman.cakir@erdogan.edu.tr
}

bstract: Considering the strategic
importance of innovation activities,
various studies have been employed
pertaining to gauging innovation
performance both micro and macro levels. While theoretical frameworks to identify and measure capabilities of the national innovation systems (NISs) of countries do exist, what remains striking is the lack of thorough account of the structural and dependence relationships expressed in a series of equations. Dedicated to remedy this research gap of the literature, the main purpose of this study is to develop and test a hypothesized model through the PLS-SEM approach for the NISs of European countries. The developed model enables decision makers concerned with innovation to comprehend the dynamics of innovation systemically and to have valid and reliable variables which represent the antecedents of national innovation capabilities of the EU countries.

Keywords: National innovation systems, PLS-SEM approach, antecedents of innovation. 


\section{KISMİ EN KÜÇÜK}

\section{KARELER-YAPISAL EŞITLIIK \\ MODELİ (PLS-SEM) İLE AB \\ Hacettepe Üniversitesi \\ iktisadi ve Idari Bilimler \\ Fakültesi Dergisi, \\ Cilt 35, Sayı 3, 2017 \\ s. $19-42$ \\ ÜLKELERİNİN ULUSAL İNOVASYON \\ SISTEMLERININ MODELLENMESI}

\author{
Süleyman ÇAKIR \\ Yrd.Doç.Dr. Recep Tayyip Erdoğan \\ Üniversitesi \\ İktisadi ve İdari Bilimler Fakültesi \\ İşletme Bölümü \\ suleyman.cakir@erdogan.edu.tr
}

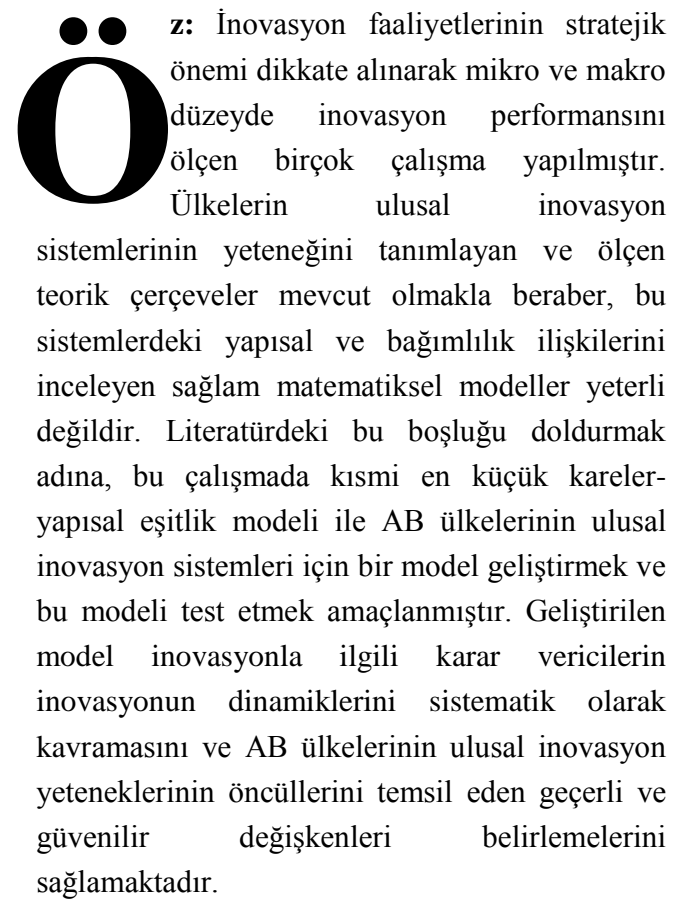

Anahtar Sözcükler: Ulusal inovasyon sistemleri, kısmi en küçük kareler-yapısal eşitlik modeli, Inovasyonun öncülleri. 


\section{INTRODUCTION}

Since a national innovation system (NIS) of a country is of crucial importance for accelerating competitiveness and enhancing economic performance, countries worldwide are making serious effort to augment their national innovative capacity. The performances of NISs largely rely on how those actors, which encapsulate government, enterprises, universities, public and private research institutes and other contributing institutions function and interact with each other to develop and carry out innovative knowledge (Chang, Shih, 2004). In an effort to assign limited resources efficaciously via targeted strategy, appraising and thereby managing the interactions of the core actors within the NIS is essential (Bartels et al., 2009).

Considering the strategic importance of innovation activities, various studies have been employed pertaining to gauging innovation performance both micro and macro levels. However, what have been neglected in those studies are the potential structural relationships among the innovation factors/indices. The most appropriate approach to capturing this kind of behavior of factors is the structural equation modeling (SEM). SEM's ability to simultaneously examine relationships incorporated into an integrated model has contributed to its widespread application (Yoon et al., 2001; Duncan, Elliot 2004; Ar, Baki, 2011; Jenatabadi, Ismail 2014; Fullerton, et al., 2014).

Covariance-based SEM (CB-SEM) (Joreskog, 1978, 1982) and Partial-leastsquares-based SEM (PLS-SEM) (e.g. Lohmoller, 1989; Wold, 1982) are the two primary techniques for estimating structural equation models. While CB-SEM has been the predominant approach, the use of PLS-SEM has been accelerated in recent years in a variety of disciplines. PLS-SEM is preferable to CB-SEM when the research focus lies in identifying relationships instead of confirming (Sarstedt et al., 2014a). Besides, as it uses only few observations without imposing distributional assumptions (e.g. normality) on the data, the PLS-SEM approach relaxes the demands on data and specification of relationships set by CB-SEM. While theoretical frameworks to identify and measure capabilities of the NISs of countries do exist, what remains striking is the lack of thorough account of the structural and dependence relationships expressed in a series of equations. Dedicated to remedy this research gap of the literature, the main purpose of this study is to develop and test a hypothesized model for the NISs of EU countries in order to better understand the complex relationships between innovation indices and interrelatedness of the indicators through the PLS-SEM approach.

The remaining of the paper unfolds as follows. Firstly, a critical analysis of the previous research with respect to measurement of national innovation capabilities is provided. Then, the conceptual framework of the case study and hypotheses development are given in the second section. The paper next presents the research 
methodology and empirical validation of the suggested framework in the third section and finally, concludes with a discussion of the results obtained.

\section{RECENT STUDIES ON NIS}

NISs have already been analyzed for different countries resulting in a rich sample of variety of participating institutions and organizations in order to reveal the structure of national innovation processes and the main involved actors (Samara et al., 2012). These studies can be grouped in two main categories. The first category contains policy-oriented studies that combine the NIS approach with the terminology of corporate benchmarking. The works of Freeman (1987), Porter (1990), Lundvall (1992), Nelson et al. (1993), Edquist et al. (1997), Lundvall (1998) and Carlsson et al. (2002) can be included in this category. Nelson et al. (1993), examined institutions and mechanisms which support technical innovation, showing similarities, differences, and their sources across seventeen countries from large market-oriented industrialized ones to several smaller high income ones. Edquist et al. (1997), investigated some conceptual problems associated with the systems of innovation approach; relating the systems of innovation approach to innovation theories, particularly of an evolutionary kind. Carlsson et al. (2002) focused on some analytical and methodological issues particularly important in the analysis of technological systems, but which are also relevant in other approaches to innovation systems.

These examinations have defined the link between innovation and competitive and economic outcomes at the national level and their findings have been broadly adopted in the national science\&technology policy research domain (Yam et al., 2011). However, those descriptive studies have not been aimed at providing a formalized methodology of the NIS concept. These drawbacks have urged research efforts to conduct system-level comparisons as well as to formalize the NIS concept. These efforts have led to the development of analytical models. The works of the second category centered to cultivate models to exert international comparisons of innovative capability. The main approaches carried out in these studies are Data envelopment analysis (DEA) method (Rousseau, Rousseau 1997; Nasierowski, Arcelus 2003; Pan et al., 2010; Abbasi et al., 2011; Guan, Chen, 2012) and statistical techniques such as cluster analysis techniques and factor analysis methods (Spielkamp, Kaprin, 1998; Liu, White, 2001; Chang, Shih, 2004; Marklund et al., 2004; Balzat, Pyka, 2006; Fagerberg, Srholec, 2008). Even though mathematical techniques provide valuable insights regarding the dynamics of innovation process and the effect of innovation policies on the performances of NIS, there are still interactions and structural relationships among innovation factors disregarded in the cited studies. 
The studies investigated national innovative capacity levels with a SEM is scarce. Sohn et al. (2015) proposed a SEM based on the Global Innovation Index (GII), which includes seven factors representing inputs (institution, human capital and research, infrastructure, market sophistication, and business sophistication) and outputs (knowledge and technology outputs, and creative outputs). Using GII data, they concluded that business sophistication and infrastructure have the strongest direct and indirect effects on creative output, respectively. Ghazinoory et al. (2014) investigated the influence of four different dimensions of social capital (institutional and interpersonal, associational life and norms) on two of the main functions of NIS (entrepreneurship and knowledge creation) based on over 50,000 observations in 34 countries via exploratory factor analysis and SEM approach. Research findings suggested the strong positive effect of institutional trust and networking on entrepreneurship. Also, interpersonal trust and networks were shown to have high influence on knowledge development at the national level. Ju and Sohn (2014) proposed a national competitiveness index using raw Institute of Management Development (IMD) data considering the structural relationships among various factors. They used a SEM to derive a national competitiveness index that reflects such structural relationships. Mokhtarzadeh and Zarei (2014) tried to determine the effects of NIS functions on attracting foreign direct investment via SEM. Findings of the study indicated that NIS functions have a direct effect on increasing foreign direct investment. Bartels et al. (2014) examined the efficacy of the NIS of Ghana through SEM using empirical data on the Ghana NIS. They found that the efficacy of the NIS of Ghana was measureable by factors that influence incentives, innovation capacity and standards.

\subsection{National Innovation Indices}

Various supra-national organizations have introduced national innovation indices, which can specify the degree of national innovative capacity. In this section, the innovation indices/indicators developed by global organizations and utilized by the researchers in the literature have been reviewed. The OECD publishes Science, Technology and Industry Scoreboard, a biennial statistical publication that brings together over 200 figures to help examine emerging policy issues in science and technology including the growth of the information economy and innovation by regions and industries. Besides, the OECD publishes Main Science and Technology Indicators that reflect the level and structure of the efforts undertaken by OECD member countries and selected non-member economies in the field of science and technology from 1981 onwards.

The European commission issues Innovation Union Scoreboard (IUS) based on 8 innovation dimensions and 25 indicators to analyze the performance of the EU innovation system. The Worldbank publishes annually World development indicators including technological innovation indicators. These indicators aim to shed light on 
ÇAKIR | Kısmi En Küçük Kareler-Yapısal Eşitlik Modeli (PLS-SEM) İle AB Ülkelerinin...

countries technology base: $R \& D$, scientific and technical journal articles, hightechnology exports, royalty and license fees, and patents and trademarks.

The World Economic Forum (WEF) publishes annual Global Competitiveness Report, which assesses the competitiveness landscape of 140 economies, providing insight into the drivers of their productivity and prosperity. The WEF has based its competitiveness analysis on the Global Competitiveness Index (GCI), a comprehensive tool that measures the microeconomic and macroeconomic foundations of national competitiveness. Besides, the WEF issues annually Networked Readiness Index (NRI) in collaboration with INSEAD. The NRI is a composite indicator made up of four subindexes, 10 subcategories (pillars), and 53 individual indicators.

The mostly used indicators by the authors to measuring NIS capabilities of countries worldwide and the performances of firm innovation systems (FISs) in the literature are listed in Table 1 below.

Table 1. The Innovation Indicators Used in Previous Studies

\begin{tabular}{|c|c|}
\hline Indicators/indices & References \\
\hline Non-business R\&D expenditures & $\begin{array}{l}\text { Zhang (2013), Abbasi et al. (2011), Pan et al. } \\
\text { (2010) }\end{array}$ \\
\hline Business sector R\&D expenditures & Liu et al. (2015), Marklund et al. (2004) \\
\hline The number of R\&D personnel & $\begin{array}{l}\text { Kou et al. (2016), Wiseman, Anderson (2012), } \\
\text { Cai (2011) }\end{array}$ \\
\hline Number of doctorate students & Matei, Aldea (2012), IUS indicator \\
\hline Government expenditure on education & $\begin{array}{l}\text { Mahroum et al. (2008), Nasierowski, Arcelus } \\
\text { (2003), IUS indicator, GII indicator }\end{array}$ \\
\hline Government expenditure on tertiary education & Sohn et al. (2015), IUS indicator, GII indicator \\
\hline Number of scientific articles & $\begin{array}{l}\text { Castellacci, Natera (2013), Furman et al. } \\
\text { (2002) }\end{array}$ \\
\hline Innovative enterprises & Samara et al. (2012), IUS indicator \\
\hline Innovative enterprises cooperating with others & Guan, Chen (2012), Hsu (2011), IUS indicator \\
\hline High-tech exports & Hsu (2011), Zhang (2013), Afzal, (2014) \\
\hline Patent applications filed under the PCT & Lu et al. (2014), Rousseau, Rousseau (1997), \\
\hline Community trade mark (CTM) applications & Matei, Aldea (2012), Millot (2009) \\
\hline Community design (CD) applications & Hollanders, Cruysen (2009), IUS indicator \\
\hline Employment in hi-tech sectors & $\begin{array}{l}\text { Tong, Liping (2009), Hollanders, Esser (2007), } \\
\text { Evangelista, Savona (2002), }\end{array}$ \\
\hline Added-value of industries & Marklund et al. (2004), \\
\hline Turnover from innovation & $\begin{array}{l}\text { Feigl, Menrad (2008), Hollanders, } \\
(2007),\end{array}$ \\
\hline $\begin{array}{l}\text { Information and communication technology } \\
\text { (ICT) service exports }\end{array}$ & Kazazoğlu (2014), GII indicator. \\
\hline
\end{tabular}




\section{CONCEPTUAL FRAMEWORK AND HYPOTHESES DEVELOPMENT}

The theoretical foundation of this study has been ascertained mainly by reviewing the literature and considering the data availability of the variables. As a result, 24 measures have been elicited initially, which are grouped in four constructs. Figure 1 depicts the research model.

Figure 1. The Proposed Research Model

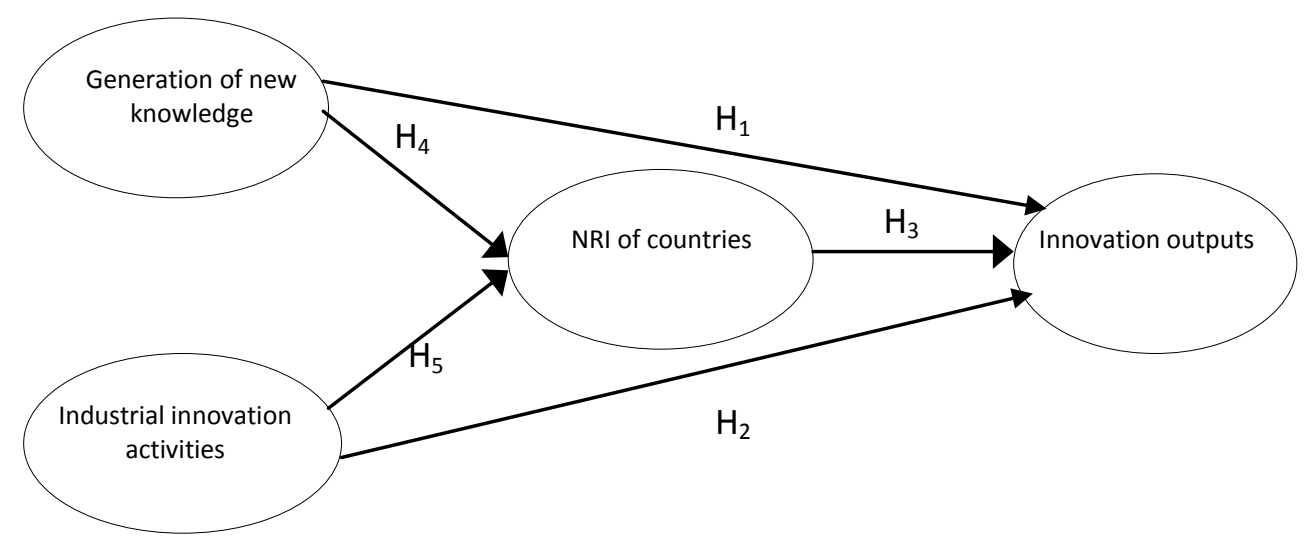

The three factors of new knowledge generation, industrial innovation activities and NRI of countries are designed to explain the variation on the innovation output construct. In addition, a mediation model were constituted by incorporating NRI of countries between generation of new knowledge and innovation outputs and between industrial innovation activities and innovation outputs in order to assess direct and indirect effects of these LVs on the output. What is provided next is the presentation of the research models' hypotheses between the mentioned four constructs.

\subsection{Generation of new knowledge and Innovation outputs}

The generation of new knowledge is a vital element for future innovative capacity and is strongly influenced by R\&D activities and the supply of skilled human resources (Freudenberg, 2003). Several studies indicated a significant relationship between innovation outcomes and R\&D activities and investment in organizations (Kou et al., 2016; Liu et al., 2015; Wiseman, Anderson 2012; Cai, 2011). According to Morris-King (2014) innovation is essentially driven by concentrations of mature academic research institutions and is mediated by consistent government support and 
highly active industrial partners. Workers with high educational levels show more aptitude to take advantage efficiently of the know-how of the company and to translate the tacit knowledge into innovation (Vilaseca et al., 2006).

Therefore, this study focuses on the extraction of the dimensions of knowledge creation, investigates their effects on innovation outputs and proposes the following hypothesis:

Hypothesis $1\left(\mathbf{H}_{1}\right)$ : Generation of new knowledge dimensions has a direct and positive influence on innovation outputs.

\subsection{Industrial Innovation Activities and Innovation Outputs}

Industrial innovation hinges strongly on private sector investments in R\&D and their skill to develop and take advantage of new technology are important measures of the extent to which companies are innovating. While the government and the higher education sectors exercise research, industrial $R \& D$ is most closely connected to the invention of new products and production techniques, as well as to a country's innovation efforts. The incident effect of industrial activities on innovation and NIS is acknowledged (Hsu, 2011; Cai, 2011; Hollanders, Essers, 2007; Nasierowski, Arcelus, 2003).

On this basis, it is hypothesized that:

Hypothesis $2\left(\mathbf{H}_{2}\right)$ : Industrial innovation activities have a direct and positive effect on innovation outputs.

\subsection{Networked Readiness Index (NRI) and Innovation outputs}

The use of ICT boosts innovation in the companies regarding it as launching new products or services as well introducing new processes, which escalate the level of competitiveness in the enterprise (Ollo-López, Aramendía-Muneta, 2012). ICT serve as a catalyst for developing NISs that responds to and guides innovation nationwide and creates an institutionalized structure of innovation at the national and regional levels (Wiseman, Anderson, 2012). The goal of the Economic impacts pillar of the NRI delivered by OECD is to measure the effect of ICTs on the economy through technological and non-technological innovations in a country as measured by the number of patent applications as well as by the role of ICTs in the development of new products, processes, and organizational models.

Therefore, it is hypothesized that: 
Hypothesis $3\left(\mathbf{H}_{3}\right)$ : Networked Readiness Index (NRI) of EU countries has a direct and positive effect on innovation outputs

2.4. Generation of new knowledge, Industrial innovation activities and Networked Readiness Index (NRI)

ICTs are key enablers of innovation throughout all sectors of economy. In most countries information industries account for the largest share of the business expenditure on R\&D (BERD) amounting to about 20-25\% of total BERD and 0.2-0.3\% of GDP in most countries (OECD, 2014). Several recent studies indicate a significant positive relationship between $R \& D$ factors (diversity of $R \& D$ funding, $R \& D$ performance, number of researchers) and ICT innovation. (Lee et al., 2015; Gao et al., 2014; Guan, Zhao, 2013). It is suggested that the accumulation of knowledge capital through R\&D intensifies ICT innovation and ICT industry competitiveness, since R\&D can foster triple helix collaboration among academia, industry and the government for ICT innovation. Based on the above evidence, the following hypotheses are developed:

Hypothesis $4\left(\mathbf{H}_{4}\right)$ : Generation of new knowledge has a direct and positive effect on the NRI of EU countries.

Hypothesis $\mathbf{5}\left(\mathbf{H}_{5}\right)$ : Industrial innovation activities have a direct and positive effect on the NRI of EU countries.

\section{RESEARCH METHODOLOGY}

\subsection{Construct Measures}

As noted above, measures of the case application were developed based on 24 indicators (also known as manifest variables-MVs) adopted from previous research. These indicators are grouped into two exogenous LVs (i.e. generation of new knowledge and industrial innovation activities) and two endogenous LVs (NRI of countries and innovation outputs). Table 2 exhibits the LVs and MVs involved. 
ÇAKIR | Kısmi En Küçük Kareler-Yapısal Eşitlik Modeli (PLS-SEM) İle AB Ülkelerinin...

Table 2. Factor Measures and Definitions

\begin{tabular}{|c|c|c|c|c|}
\hline Zonstruct & Measure & Code & Definition & Data source \\
\hline \multirow{8}{*}{$\begin{array}{l}\text { Generation of } \\
\text { new knowledge }\end{array}$} & & GNK & & \\
\hline & $\begin{array}{l}\text { Non-business R\&D } \\
\text { expenditures }\end{array}$ & GNK1 & $\begin{array}{l}\mathrm{R} \& \mathrm{D} \text { expenditure realized by the non-business } \\
\text { sector as \% of GDP }\end{array}$ & Eurostats \\
\hline & $\begin{array}{l}\text { Non-business R\&D } \\
\text { personnel }\end{array}$ & GNK2 & $\begin{array}{l}\text { Full time equivalent non-business R\&D personnel } \\
\text { as } \% \text { of the labor force }\end{array}$ & Eurostats \\
\hline & Doctorate students & GNK3 & $\begin{array}{l}\text { Doctorate students in science and technology } \\
\text { fields as } \% \text { of the population }\end{array}$ & Eurostats \\
\hline & Scientific articles & GNK4 & $\begin{array}{l}\text { The volume of scientific and technical articles per } \\
\text { million population }\end{array}$ & $\begin{array}{l}\text { Worldbank } \\
\text { stats }\end{array}$ \\
\hline & $\begin{array}{l}\text { Non-business } \\
\text { Researchers }\end{array}$ & GNK5 & $\begin{array}{l}\text { Full time equivalent non-business researchers as } \\
\% \text { of the labor force }\end{array}$ & Eurostats \\
\hline & $\begin{array}{l}\text { Education } \\
\text { expenditures }\end{array}$ & GNK6 & $\begin{array}{l}\text { Government expenditure on education as } \% \text { of } \\
\text { GDP }\end{array}$ & $\begin{array}{l}\text { Worldbank } \\
\text { stats }\end{array}$ \\
\hline & $\begin{array}{l}\text { Expenditures on } \\
\text { tertiary education }\end{array}$ & GNK7 & $\begin{array}{l}\text { Government expenditure per tertiary student as } \% \\
\text { of GDP }\end{array}$ & $\begin{array}{l}\text { Worldbank } \\
\text { stats }\end{array}$ \\
\hline \multirow{6}{*}{$\begin{array}{l}\text { Industrial innovatio } \\
\text { activities }\end{array}$} & & IIA & & \\
\hline & $\begin{array}{l}\text { Business R\&D } \\
\text { expenditure }\end{array}$ & IIA1 & $\begin{array}{l}\text { R\&D expenditure in the business enterprise sector } \\
\text { as \% of GDP }\end{array}$ & Eurostats \\
\hline & $\begin{array}{l}\text { Business R\&D } \\
\text { personnel }\end{array}$ & IIA2 & $\begin{array}{l}\text { Business enterprise full time equivalent } R \& D \\
\text { personnel as } \% \text { of the labor force }\end{array}$ & Eurostats \\
\hline & $\begin{array}{l}\text { Innovative } \\
\text { enterprises }\end{array}$ & IIA3 & $\begin{array}{l}\text { Product and/or process (PP) innovative enterprises } \\
\text { as \% of total enterprises }\end{array}$ & Eurostats \\
\hline & $\begin{array}{l}\text { Innovative } \\
\text { enterprises in } \\
\text { cooperation }\end{array}$ & IIA4 & $\begin{array}{l}\text { PP innovative enterprises engaged in any type of } \\
\text { cooperation as \% of PP innovative enterprises }\end{array}$ & Eurostats \\
\hline & $\begin{array}{l}\text { Business } \\
\text { researchers }\end{array}$ & IIA5 & $\begin{array}{l}\text { Full time equivalent business enterprise } \\
\text { researchers as } \% \text { of the labor force }\end{array}$ & Eurostats \\
\hline \multirow{4}{*}{$\begin{array}{l}\text { Networked readiness } \\
\text { index of countries }\end{array}$} & & NRI & & \\
\hline & $\begin{array}{l}\text { Environment } \\
\text { subindex }\end{array}$ & NRI1 & $\begin{array}{l}\text { The level of the friendliness of a country's market } \\
\text { and regulatory framework in supporting high } \\
\text { levels of ICT uptake }\end{array}$ & WEF report \\
\hline & Readiness subindex & $\mathrm{NRI} 2$ & $\begin{array}{l}\text { The degree to which a society is prepared to make } \\
\text { good use of an affordable ICT infrastructure }\end{array}$ & WEF report \\
\hline & Usage subindex & NRI3 & $\begin{array}{l}\text { The level of the individual efforts of the main } \\
\text { social agents to increase their capacity to use ICTs }\end{array}$ & WEF report \\
\hline \multirow[t]{10}{*}{ Innovation outputs } & & INO & & \\
\hline & Hi-tech exports & INO1 & Hi-tech exports as $\%$ of exports & Eurostats \\
\hline & ICT service exports & $\mathrm{INO} 2$ & ICT service exports as $\%$ of service exports & $\begin{array}{l}\text { Worldbank } \\
\text { stats }\end{array}$ \\
\hline & Patent applications & INO3 & Patent applications filed under the PCT & $\begin{array}{l}\text { OECD } \\
\text { iLibrary }\end{array}$ \\
\hline & $\begin{array}{l}\text { GCI of the } \\
\text { countries }\end{array}$ & INO4 & $\begin{array}{l}\text { The set of institutions, policies, and factors that } \\
\text { determine the level of productivity of a country. }\end{array}$ & $\begin{array}{l}\text { WEF } \\
\text { reports }\end{array}$ \\
\hline & $\begin{array}{l}\text { Community trade } \\
\text { mark (CTM) } \\
\text { applications }\end{array}$ & INO5 & CTM applications per billion GDP & Eurostats \\
\hline & $\begin{array}{l}\text { Community design } \\
\text { (CD) applications }\end{array}$ & INO6 & CD applications per billion GDP & Eurostats \\
\hline & $\begin{array}{l}\text { The value- } \\
\text { added contribution }\end{array}$ & INO7 & $\begin{array}{l}\text { The value added of industries according to ISIC } \\
\text { divisions as } \% \text { of GDP }\end{array}$ & $\begin{array}{l}\text { Worldbank } \\
\text { stats }\end{array}$ \\
\hline & $\begin{array}{l}\text { Turnover from } \\
\text { innovation }\end{array}$ & INO8 & Turnover from innovation as $\%$ of total turnover & Eurostats \\
\hline & Employment rate & INO9 & $\begin{array}{l}\text { Employment in hi-tech manufacturing sectors and } \\
\text { knowledge-intensive service sectors as \% of total } \\
\text { employment }\end{array}$ & Eurostats \\
\hline
\end{tabular}

Hacettepe Üniversitesi Iktisadi ve İdari Bilimler Fakültesi Dergisi |

Cilt 35, Sayı 3, 2017

28 


\subsection{Sample and Data Collection}

In an effort to exemplify the opportunities for the use of the PLS-SEM method to national innovation research, the influence of innovation and technology characteristics on innovation performance was examined in the context of European countries. Data availability forced us to include $32 \mathrm{EU}$ countries in total $(28$ member and four candidate countries). One of the important issues in innovation literature is the use of time lags which affects innovation outcomes. Since a certain length of time is required before innovation is completed and outputs are realized, a time lag between inputs and outputs needs to be taken into account. Based on the literature (Adams, Griliches, 2000; Wang, Huang, 2007), this study sets the time lag to be 3 years. The input data set (including generation of new knowledge, industrial innovation activities and NRI of countries) for 2009, 2010 and 2011 is thus matched with the innovation output data set for the years 2012, 2013, and 2014. Accordingly, the sample covers 96 cases with a tree-year panel data of 32 countries.

In order for CB-SEM to ensure reliable results, sample sizes in the range of 100 to 400 are suggested as a rule of thumb (Hair et al., 2014b). In the case of smaller sample sizes, as is the case in this study, a simulation study by Reinartz et al. (2009) indicated that PLS-SEM is a good choice. Moreover, compared with CB-SEM, PLSSEM has higher levels of statistical power in situations with complex model structures or smaller sample sizes. That is why PLS-SEM algorithm was decided to convey. In an effort to test the model, this study draws on SmartPLS 2.0 (Ringle et al., 2005), applying the path weighting scheme. The bootstrapping procedure draws 96 cases and 5,000 samples, using the no sign change option. In evaluating and reporting the results recent guidelines for PLS-SEM provided by Hair et al. (2014a), Sarstedt et al. (2014a), Hair et al. (2012), and Henseler et al. (2009) were followed.

\subsection{PLS-SEM Analysis}

PLS-SEM algorithm involves completing two stages: (i) measurement model evaluation and (ii) structural model evaluation. Measurement models (also referred to as the outer model) represent the relationships between constructs, i.e. unobserved or LVs and their corresponding observed or manifest variables whereas structural models (also referred to as inner model) state the relationships between LVs. If the measurement model evaluation provides satisfactory results, the researcher moves onto structural model evaluation. 


\subsubsection{Measurement model evaluation}

Because the case application encapsulates solely reflective measures, reflective model assessment was involved. Reflective measurement model evaluation mainly covers the following three steps, respectively: (i) Internal consistency (ii) Convergent validity (iii) Discriminant validity.

\section{Step 1: Internal consistency (composite reliability)}

Reflective measurement models should be examined with regard to their reliability and validity. Typically, the first criterion which is analyzed is internal consistency reliability. Since Cronbach's $\alpha$ prone to underestimate the internal consistency reliability of LVs in PLS path models, it is more appropriate to apply the Jöreskog's (1971) composite reliability $\left(\rho_{c}\right)$. It is generally interpreted in the same way as Cronbach's $\alpha$, such that values below 0.60 indicate a lack of internal consistency reliability while values above 0.60 are acceptable in exploratory research (Nunnally, Bernstein, 1994). Values higher than 0.95 are deemed problematic, as they signal that the items are redundant, leading to issues such as undesirable response patterns and inflated correlations among indicator error terms (Drolet, Morrison, 2001).

\section{Step 2. Convergent validity}

For the assessment of validity, the convergent validity and the discriminant validity are the two typically investigated validity subtypes. The outer loadings of the indicators and the average variance extracted (AVE) are concerned by the researchers to establish convergent validity. Accordingly, the absolute correlations between a construct and each of its manifest variables (i.e. the absolute standardized outer loadings) should be higher than $0.70(\approx \sqrt{0.5})$. Generally, indicators with outer loadings between 0.40 and 0.70 should be considered for removal from the scale only when omitting the indicator leads to an increase in the composite reliability (CR) or the AVE above the suggested threshold value (Hair et al., 2014a). The AVE value is computed as the mean of the squared loadings for all indicators associated with a construct. An AVE value of at least 0.5 indicates sufficient convergent validity, meaning that a LV is able to explain more than half of the variance of its indicators on average. Based on the above criteria, measurement model is evaluated by iterative process to discard the weak indicator variables from the developed model. Table 3 summarizes the first and final iterations only. 
Table 3. Results of Measurement Model Evaluation

\begin{tabular}{|c|c|c|c|c|c|c|c|c|}
\hline & \multicolumn{4}{|c|}{ First iteration } & \multicolumn{4}{|c|}{ Final iteration } \\
\hline & $\begin{array}{l}\text { Loadi } \\
\text { ng }\end{array}$ & AVE & $\mathrm{CR}$ & Alpha & Loading & AVE & $\mathrm{CR}$ & Alpha \\
\hline GNK1 & 0.878 & 0.483 & 0.862 & 0.813 & 0.928 & 0.690 & 0.898 & 0.849 \\
\hline GNK2 & 0.700 & & & & 0.762 & & & \\
\hline GNK3 & 0.587 & & & & 0.709 & & & \\
\hline GNK4 & 0.908 & & & & 0.903 & & & \\
\hline GNK5 & 0.527 & & & & Omitted & & & \\
\hline GNK6 & 0.592 & & & & Omitted & & & \\
\hline GNK7 & 0.566 & & & & Omitted & & & \\
\hline IND1 & 0.936 & 0.770 & 0.901 & 0.913 & 0.941 & 0.775 & 0.911 & 0.854 \\
\hline IND2 & 0.966 & & & & 0.950 & & & \\
\hline IND3 & 0.574 & & & & Omitted & & & \\
\hline IND4 & 0.686 & & & & 0.733 & & & \\
\hline IND5 & 0.961 & & & & Omitted & & & \\
\hline NRI1 & 0.970 & 0.895 & 0.934 & 0.944 & Omitted & 0.897 & 0.946 & 0.887 \\
\hline NRI2 & 0.910 & & & & 0.938 & & & \\
\hline NRI3 & 0.945 & & & & 0.957 & & & \\
\hline INO1 & 0.656 & 0.334 & 0.639 & 0.588 & Omitted & 0.852 & 0.945 & 0.913 \\
\hline INO2 & 0.909 & & & & 0.888 & & & \\
\hline INO3 & 0.856 & & & & 0.933 & & & \\
\hline INO4 & 0.905 & & & & 0.946 & & & \\
\hline INO5 & 0.248 & & & & Omitted & & & \\
\hline INO6 & 0.148 & & & & Omitted & & & \\
\hline INO7 & -0.185 & & & & Omitted & & & \\
\hline INO8 & -0.282 & & & & Omitted & & & \\
\hline INO9 & 0.001 & & & & Omitted & & & \\
\hline
\end{tabular}

Consequently, out of 24 measures 12 of them were omitted from the model, as they did not meet the associated conditions, i.e. CR and AVE requirements, while 12 of them were retained. The reasoning behind the deletion of NRI1 measure is its CR value of 0.970 which is higher than the cut-off value 0.95 . The remained 12 indicators have AVE values above 0.50 for the reflective constructs, hence indicating convergent validity. Composite reliabilities for the four constructs took values between 0.898 and 0.946 , exceeding the minimum requirement of 0.70 . Table 4 presents descriptive statistics and normality test of the 12 measures used for further analysis.

As PLS-SEM is a nonparametric statistical method, it does not necessitate the data to be normally distributed. Nevertheless, it is important to verify that the data are not too far from normality as extremely non-normal data prove problematic in the assessment of the parameters' significances. A general guideline for skewness and kurtosis is that if the number takes values between \pm 1 , the variables are considered normal, otherwise non-normal (Hair et al., 2014a). In this regard, as can be inferred from Table 4, due to the non-normality of some indicators having values outside the range \pm 1 , the dataset cannot be considered normally distributed. 
ÇAKIR | Kısmi En Küçük Kareler-Yapısal Eşitlik Modeli (PLS-SEM) İle AB Ülkelerinin...

Table 4. Descriptive Statistics and Normality Tests of the Case Variables

\begin{tabular}{llrrrrrr}
\hline Construct & Indicator & \multicolumn{1}{l}{ Min } & \multicolumn{1}{l}{ Max } & \multicolumn{1}{l}{ Mean } & Std. Dev. & Kurtosis & Skewness \\
\hline $\begin{array}{l}\text { Gen.of new } \\
\text { knowledge }\end{array}$ & & & & & & & \\
& GNK1 & 0.190 & 1.320 & 0.644 & 0.25 & -0.462 & 0.354 \\
& GNK2 & 0.170 & 1.150 & 0.512 & 0.187 & 1.499 & 0.627 \\
& GNK3 & 0.01 & 1.300 & 0.436 & 0.275 & 1.464 & 1.152 \\
& GNK4 & 63.58 & $1,252.33$ & 499.345 & 324.548 & -0.838 & 0.478 \\
$\begin{array}{l}\text { Industrial } \\
\text { innov.act. }\end{array}$ & & & & & & & \\
& IIA1 & 0.07 & 2.680 & 0.950 & 0.695 & -0.498 & 0.698 \\
& IIA2 & 0.06 & 1.460 & 0.529 & 0.386 & -0.600 & 0.590 \\
& IIA4 & 20.700 & 80.000 & 48.082 & 12.394 & -0.162 & -0.094 \\
NRI of & & & & & & & \\
countries & & & & & & & \\
& NRI2 & 4.120 & 6.520 & 5.595 & 0.532 & -0.074 & -0.422 \\
$\begin{array}{l}\text { Innovation } \\
\text { outputs }\end{array}$ & NRI3 & 3.500 & 6.06 & 4.740 & 0.746 & -1.344 & 0.123 \\
& & & & & & & \\
& INO2 & 10.39 & 42.56 & 27.497 & 7.473 & -0.718 & 0.04 \\
& INO3 & 2.320 & 347.88 & 89.896 & 96.669 & 0.092 & 1.092 \\
& INO4 & 3.850 & 5.740 & 4.770 & 0.520 & -1.313 & 0.203 \\
\hline
\end{tabular}

Step 3. Discriminant validity

Once the reliability and convergent validity of reflective constructs are successfully established, the next step is to assess the discriminant validity of the constructs. In PLS-SEM, two measures of discriminant validity have been developed: The Fornell-Larcker criterion and the cross-loadings. The Fornell-Larcker criterion (Fornell, Larcker 1981) assumes that a LV shares more variance with its assigned indicators than with any other LV. Specifically, the square root of each construct's AVE should be greater than its highest correlation with any other construct. That is to say, the AVE should exceed the squared correlation with any other construct. The second criterion for the discriminant validity is more liberal: the loading of each indicator is to be greater than all of its cross-loadings (Chin, 1998). Table 5 demonstrates the AVE values on the diagonal and the squared interconstruct correlations off the diagonal.

As illustrated in Table 5, all AVE values are higher than the squared interconstruct correlations, indicating discriminant validity. Similarly, all indicator loadings were higher than their respective cross loadings (data not shown for brevity), exhibiting evidence of discriminant validity. 
Table 5. The AVE Values and Discriminant Validity Test

\begin{tabular}{lllll}
\hline Construct & GNK & IAC & NRI & INO \\
\hline GNK & 0.831 & & & \\
IAC & 0.788 & 0.880 & & \\
NRI & 0.791 & 0.810 & 0.947 & \\
INO & 0.795 & 0.827 & 0.884 & 0.827 \\
\hline
\end{tabular}

\subsubsection{Structural Model Evaluation (Quality of the Structural Model)}

Having confirmed that the construct measures are reliable and valid, the next step involves the assessment of the structural model results by investigating the model's predictive capabilities and the relationships between the constructs. Instead of performing measures of goodness-of fit (GOF), the assessment of the model's quality is rest on its ability to predict the endogenous constructs. The following criteria facilitate this assessment: coefficient of determination $\left(R^{2}\right)$, the $\mathrm{f}^{2}$ effect size and the path coefficients (Sarstedt et al., 2014b). Prior to these analyses, the structural model for potential collinearity between the predictor constructs should be tested so as to ascertain that the regression results are not biased by collinearity issues.

\section{Step 1: Collinearity Assessment}

Similar to the assessment of formative measurement models, the tolerance levels below 0.20 (VIF above 5.00) in the predictor constructs were considered as indicative of collinearity. VIF values of the analyses ranged between 2.637 and 3.545, providing confidence that the structural model results are not negatively affected by collinearity.

\section{Step 2: Coefficient of Determination $\left(R^{2}\right.$ Value)}

The $R^{2}$ coefficient is a measure of the model's predictive accuracy and is calculated by the squared correlation between a specific endogenous construct's actual and predicted values. The coefficient represents the exogenous LVs' combined effects on the endogenous LV. According to Chin (1998), $R^{2}$ values of 0.67, 0.33, and 0.19 in PLS path models are substantial, moderate and weak, respectively.

The examination of the endogenous constructs' predictive power (Figure 2) demonstrates that innovation output, the primary outcome of the model, has a substantial $R^{2}$ value of 0.836 . Thus, the model is considered to have substantial degree of explained variance of innovation outputs by inhibiting factors. Similarly, the combined effect of generation of new knowledge and industrial innovation activities on the NRI of EU countries is substantial with a $R^{2}$ value of 0.718 . 
Figure 2. Path model and PLS-SEM estimates

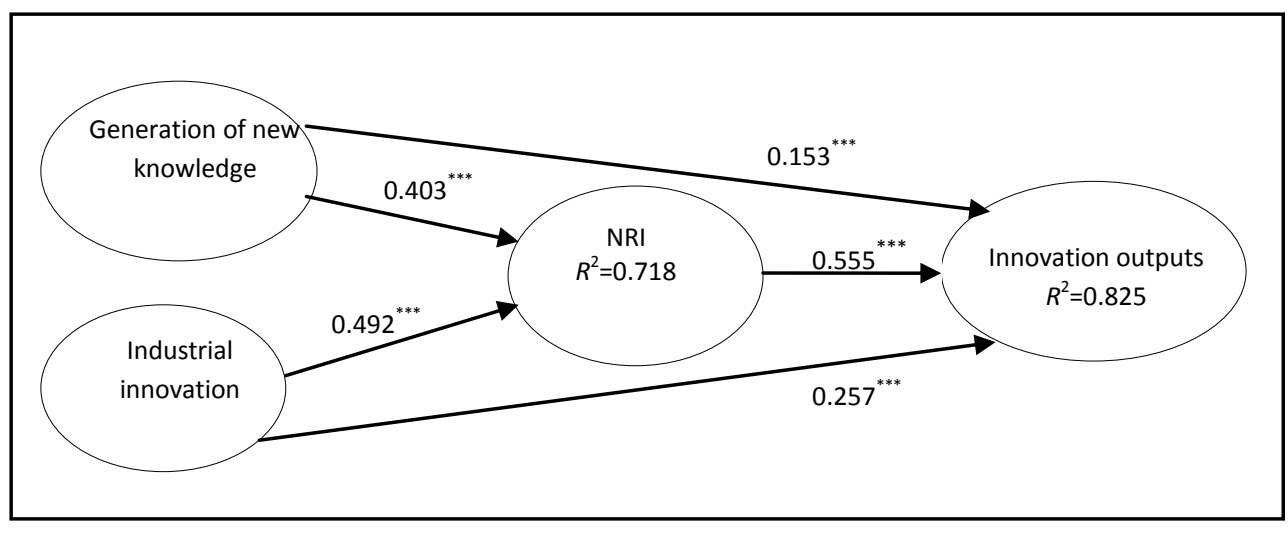

$* * * \mathrm{p} \leq 0.01$

\section{Step 3: Effect Size $\left(\mathrm{f}^{2}\right)$}

In addition to evaluating the $R^{2}$ values of all endogenous constructs, the change in the $R^{2}$ value when a specified exogenous construct is omitted from the model can be used to evaluate whether the omitted construct has a substantive impact on the endogenous constructs. This measure is referred to as the $\mathrm{f}^{2}$ effect size. Values of 0.02 , 0.15 , and 0.35 can be viewed as a gauge for whether a predictor LV has a weak, medium, or large effect at the structural level (Cohen, 1988). The $\mathrm{f}^{2}$ values of LVs are denoted in Table 6.

Table 6. Effect size $\left(\mathbf{f}^{2}\right)$ of constructs

\begin{tabular}{lcc}
\hline & INO & NRI \\
\hline GNK & 0.041 & 0.219 \\
IIA & 0.168 & 0.326 \\
NRI & 0.497 & \\
\hline
\end{tabular}

Accordingly, as seen in Table 6, generation of new knowledge has a weak effect on the innovation outputs while industrial innovation activities and NRI of countries have medium and large effects, respectively. Likewise, NRI of EU countries has a large effect size on innovation outputs as its $\mathrm{f}^{2}$ value $(0.497)$ is higher than the cut-off value 0.35 .

\section{Step 4: Path Coefficients of Structural Model}

The final stage of the structural model analysis addresses the significance and relevance of the structural model relationships hypothesized between the constructs. 
After running the PLS-SEM algorithm, estimates were obtained for the structural model relationships (i.e., the path coefficients), which represent the hypothesized relationships among the constructs. Whether a coefficient is significant ultimately hinges on its standard error that is obtained thanks to bootstrapping. The bootstrap standard error allows computing the empirical $t$ value. Having employed the bootstrapping procedure (96 cases, 5000 samples, no sign changes option) the results displayed in Table 7 were obtained. Accordingly, it is revealed that all 5 hypotheses, i.e. structural relationships, are significant at $\rho \leq 0.01$

Table 7. Summary of the Structural Model

\begin{tabular}{lccccc}
\hline Path & Hypothesis & Path coefficients & $t$-statistics & $\rho$-values & Supported? \\
\hline GNK- > INO & $\mathrm{H}_{1}$ & 0.153 & 2.652 & 0.008 & Yes \\
IIA- > INO & $\mathrm{H}_{2}$ & 0.257 & 3.467 & 0.001 & Yes \\
NRI - > INO & $\mathrm{H}_{3}$ & 0.555 & 8.997 & 0.000 & Yes \\
GNK- > NRI & $\mathrm{H}_{4}$ & 0.403 & 4.133 & 0.000 & Yes \\
IIA- > NRI & $\mathrm{H}_{5}$ & 0.492 & 5.387 & 0.000 & Yes \\
\hline
\end{tabular}

The NRI of countries has the largest direct effect on innovation outputs with path coefficient of 0.555 while industrial innovation activities and generation of new knowledge constructs have important effects with $\beta$ coefficients of 0.257 and 0.153 , as well. Besides, generation of new knowledge and industrial innovation activities LVs have direct and strong impacts on NRI of countries with $\beta$ coefficients of 0.403 and 0.492 , respectively.

\subsubsection{Mediation Analysis}

The total effect of a relationship between two constructs is the sum of all the direct and indirect effects in the structural model: total effect= direct effect + indirect effect. Accordingly, the total effect of generation of new knowledge on innovation outputs can be computed as: $0.153+(0.403 * 0.555)=0.377$. The standardized direct, indirect and total effects of the variables and their significance are exhibited in Table 8.

Table 8. The Standardized Direct, Indirect and Total Effects

\begin{tabular}{lccc}
\hline Relationships variable & Direct effects & Indirect effects & Total effects \\
\hline GNK - > INO & $0.153^{* * *}$ & $0.224^{* * * *}$ & $0.377^{* * * *}$ \\
IIA - > INO & $0.257^{* * *}$ & $0.273^{* * *}$ & $0.530^{* * *}$ \\
NRI - > INO & $0.555^{* * *}$ & - & $0.555^{* * *}$ \\
GNK - > NRI & $0.403^{* * *}$ & - & $0.403^{* * *}$ \\
IIA - > NRI & $0.492^{* * *}$ & - & $0.492^{* * *}$ \\
\hline
\end{tabular}

$* * * \rho \leq 0.01$ 
From a theoretical perspective, the most common application of mediation is to explain why a relationship between an exogenous and endogenous construct exists. In order to analyze the mediator effect of NRI of countries construct, our analysis draws on Hair et al. (2014a) by answering the following three research questions:

(i) Is the direct effect between generation of new knowledge and innovation outputs significant when the mediator variable is excluded from the path model,

(ii) Is the indirect effect via the mediator variable significant after NRI of countries is included in the path model and

(ii) How much of the direct effect does the indirect effect absorb via the mediator?

To answer the first question, NRI of countries is excluded from the path model and bootstrapping routine is conducted with the previously described specifications. As a result, the direct effect of generation of new knowledge on innovation outputs is 0.371 and significant at $\rho \leq 0.01$. Answering the second question requires re-estimating the full model (i.e., with the mediator included) and testing the indirect effect's significance. The corresponding bootstrapping results indicate that the indirect effect of 0.224 is significant at $\rho \leq 0.01$ which means that the mediator NRI of countries absorbs some of the direct effect. The question is how much the mediator variable absorbs. Thanks to the variance accounted for $(V A F)$ one can determine the extent to which the variance of the dependent variable is directly explained by the independent variable and how much of the target construct's variance is explained by the indirect relationship via the mediator variable (Hair et al., 2014a). The VAF is calculated by:

$$
V A F=\frac{\text { indirecteffect }}{\text { totaleffect }}
$$

If $V A F$ takes a value less than $20 \%$, one can conclude that (almost) no mediation takes place. In contrast, when the $V A F$ has very large scores of above $80 \%$, one can assume a full mediation. Situations in which the $V A F$ is larger than $20 \%$ and less than $80 \%$ can be characterized as partial mediation. Accordingly, the VAF score of the generation of new knowledge construct is calculated 0.594 (0.224/0.377), which suggests that NRI of countries partially mediates the relationship between generation of new knowledge and innovation output. Likewise, the VAF score of the industrial innovation activities is computed as $0.515(0.273 / 0.53)$, which indicates partial mediation, as well. 


\section{CONCLUSIONS}

Exploiting the explanatory abilities of PLS-SEM for theory testing, this study attempted to develop and test a hypothesized model representing the potential antecedents of NISs of EU countries. The findings discovered that NRI of countries with a $\beta$ coefficient 0.555 is the key significant antecedent of innovation outputs. This implies that promoting the good use of affordable ICT infrastructure and enhancing the level of the individual use of ICTs will substantially increase the volume of patent applications, ICT service exports and productivity of the countries. This finding is compatible with the findings of recent literature. Several studies presented evidence that technology not only plays a key role in creating new products or processes, it shifts the fundamentals of industry structure by radically redefining 'the rules of competition' as well (Prajogo and Ahmed, 2006). Industrial innovation activities factor has proven to have stronger direct and indirect impact on innovation outcomes than that of the generation of new knowledge factor. This implies that business enterprise sector innovation infrastructure and sector's investments on R\&D much contribute to the innovation capabilities of nations than those of the non-business sector. Besides, it can also be inferred that R\&D's role in designating innovation performance is not confined to manufacturing but applies equally to the service industry (Chiaromonte, 2002). Generation of new knowledge has the weakest direct effect on the innovation output with $\beta$ coefficient 0.153 which indicates the inefficiency of public investments on innovation infrastructure. Thus, the policy-makers should more focus on allocating limited resources effectively.

In regards to the explained variance of the construct NRI of countries, industrial innovation activities has slightly more contributed $(\beta=0.492)$ than generation of new knowledge $(\beta=0.403)$ which infers that an increase of innovation related investments in business enterprise sector will strongly increase the level of innovation outputs. Furthermore, the analysis of the mediating relationships in the PLS path model improved our insight of the relationships between the constructs since it penetrated deeper into the cause and effect of these relationships, indicating the strength of direct and indirect effects. These rich findings may initiate the refinement or development of new models or theories in the NIS approach.

Regarding the limitations of this study, first, it should be stressed that the path dependencies were tested and conclusions were drawn based on only 96 observations of 32 countries. Thus, one must be cautious in interpreting the obtained results and generalizing the research findings and implications. Second, the lack of a global GOF measure is traditionally considered the major shortcoming of PLS-SEM. Third; the availability of data restricted the number of the variables used in developing the proposed conceptual framework. Other measures such as the supply of skills, taxation 
ÇAKIR | Kısmi En Küçük Kareler-Yapısal Eşitlik Modeli (PLS-SEM) İle AB Ülkelerinin...

policy and accounting regulations, industrial regulation including environmental regulation, health standards, quality controls, standardization and so on can also promote innovation performance, or restrict it. Future works would extend the model to higher levels of abstraction to obtain a more comprehensive view of the development of national innovation performance.

\section{REFERENCES}

Abbasi, F., H. Hajihoseini, S. Haukka (2011), "Use of Virtual Index for Measuring Efficiency of Innovation Systems: A Cross-Country Study", International Journal of Technology Management and Sustainable Development, 9(3), 195-212.

Adams, J.D., Z. Griliches (2000), "Research Productivity in a System of Universities", in: Encaoua, D. (Eds.), The Economics and Econometrics of Innovation, Boston: Kluwer Academic Publishers.

Afzal, M.N.I. (2014), “An Empirical Investigation of The National Innovation System (NIS) Using Data Envelopment Analysis (DEA) and the TOBIT Model", International Review of Applied Economics, 28(4), 507-523.

Ar. İ.M, B. Baki (2011), "Antecedents and Performance Impacts of Product versus Process Innovation”, European Journal of Innovation Management, 14 (2), 172 - 206.

Balzat, M., A. Pyka (2006), "Mapping National Innovation Systems in the OECD Area", International Journal of Technology and Globalization, 2, 158-176.

Bartels, F.L, M. Eicher, C. Bachtrog, G. Rezonja (2009), "Foreign Direct Investment in SubSaharan Africa: Changing Location-Specific Advantages as Signals of Competitiveness", The Developing Economies, 47, 244-78.

Bartels, F.L., R. Koria, A. Torriero, B. Cravenna, C. Strinati (2014), "National Systems of Innovation: A Structural Model Analysis of Efficacy-The Case of Ghana", Innovation Forum, Paris.

Cai, Y. (2011), "Factors Affecting The Efficiency of the BRICS' National Innovation Systems: A Comparative Study Based on DEA and Panel Data Analysis, Economics (Open EJournal)", Economics Discussion Papers, No. 2011-52.

Carlsson, B., S. JacobssonHolmen, M., Rickne (2002), "Innovation System: Analytical and Methodological Issues”, Research Policy, 31, 233-245.

Castellacci, F., J.M. Natera (2013), "The Dynamics of National Innovation Systems: A Panel Cointegration Analysis of the Coevolution between Innovative Capability and Absorptive Capacity", Research Policy, 42, 579- 594.

Chang, P.L., H.Y. Shih (2004), "The Innovation System of Taiwan and China: A Comparative Analysis”, Technovation, 24, 529-539.

Chiaromonte, F., (2002), “Innovation and R\&D Management: Are New Paradigms Observable?", International Journal of Technology Management, 23, 374-409.

Chin, W.W. (1998), “The Partial Least Squares Approach to Structural Equation Modeling”, In: Marcoulides, G.A. (Eds.), Modern Methods for Business Research, 295-358. 
Cohen, J. (1988), Statistical Power Analysis for the Behavioral Sciences (2nd Ed.), Hillsdale, NJ: Lawrence Erlbaum Associates.

Drolet, A.L., D.G. Morrison (2001), "Do We Really Need Multiple-Item Measures In Service Research?”, Journal Of Service Research, 3, 196-204.

Duncan, E., G. Elliott (2004), "Efficiency, Customer Service and Financial Performance among Australian Financial Institutions”, International Journal of Bank Marketing, 22, 319 342.

Edquist, C., L. Hommen, M. Mckelvey (1997), "Product vs. Process Innovation, Productivity Growth and Employment", In Reati, A., and Michie, J. (Eds.), Work, Employment and Need: Theory and Evidence, London, UK: Edward Elgar Publishers.

Evangelista, R., M. Savona (2002), "The Impact of Innovation on Employment in Services: Evidence from Italy", International Review of Applied Economics, 16, 309-318.

Fagerberg, J., M. Srholec (2008), "National Innovation Systems, Capabilities and Economic Development", Research Policy, 37, 1417-1435.

Feigl, S., K. Menrad (2008), "Innovation Activities in the Food Industry in Selected European Countries. Report for TRUEFOOD Project", Germany: University of Applied Sciences of Weihenstephan.

Freeman, C. (1987), Technology and Economic Performance: Lessons from Japan, London: Printer Pub. Ltd.

Freudenberg, M. (2003), "Composite Indicators of Country Performance: A Critical Assessment, OECD Science, Technology and Industry Working Papers”, (2003)/16, OECD Publishing.

Fornell, C., Larcker, D.F. (1981), "Evaluating Structural Equation Models with Unobservable Variables and Measurement Error", Journal of Marketing Research, 18, 39-50.

Fullerton, R.R., F.A. Kennedy, S.K. Widener (2014), "Lean Manufacturing and Firm Performance: The Incremental Contribution of Lean Management Accounting Practices", Journal of Operations Management, 32, 414-428.

Furman, J.L., M.E. Porter, S. Stern (2002), "The Determinants of National Innovative Capacity", Research Policy, 31, 899-933.

Gao, X., X. Guo, J. Guan (2014), “An Analysis of the Patenting Activities and Collaboration Among Industry-University-Research Institutes in the Chinese ICT Sector", Scientometrics, 98, 247-263.

Ghazinoory S., A. Bitaab, A. Lohrasbi (2014), "Social Capital and National Innovation System: Across-Country Analysis”, Cross Cultural Management, 21, 453-475.

Guan, J., K. Chen (2012), "Modeling the Relative Efficiency of National Innovation Systems", Research Policy, 41, 102- 115.

Guan, J., Q. Zhao (2013), “The Impact of University-Industry Collaboration Networks On Innovation in Nano Biopharmaceuticals", Technological Forecasting and Social Change, $80,1271-1286$.

Günday, G., G. Ulusoy, K. Kilic,. L. Alpkan (2011), "Effects of Innovation Types on Firm Performance”, International Journal of Production Economics, 133, 662-676. 
ÇAKIR | Kısmi En Küçük Kareler-Yapısal Eşitlik Modeli (PLS-SEM) İle AB Ülkelerinin...

Hair, J.F., M. Sarstedt, T.M. Pieper,. C. Ringle (2012), "The Use of Partial Least Squares Structural Equation Modeling In Strategic Management Research: A Review of Past Practices and Recommendations for Future Applications", Long Range Planning, 45, 320340.

Hair, J.F., Jr. G. Tomas, M. Hult, C.M. Ringle, M. Sarstedt (2014a), A Primer on Partial Least Squares Structural Equation Modeling (Pls-Sem),: Washington DC: Sage Publications.

Hair, J.F., W.C. Black, B.J. Babin, R.E. Anderson (2014b), Multivariate Data Analysis, Edinburgh Gate: Pearson Education Limited.

Henseler, J., C.M. Ringle, R.R. Sinkovics (2009), "The Use of Partial Least Squares Path Modeling in International Marketing", Advances In International Marketing, 20, 277-320.

Hollanders H., F.C. Esser (2007), "Measuring Innovation Efficiency”, INNO-Metrics Thematic Paper.

Hollanders, H., A. Cruysen (2009), "Design, Creativity and Innovation: A Scoreboard Approach. INNO Metrics (2008) Report”, Brussels: European Commission, DG Enterprise.

Hsu, Y. (2011), "Cross National Comparison of Innovation Efficiency and Policy Application", African Journal of Business Management, 5, 1378-1387.

Jenatabadi, H.S., Ismail, N.A. (2014), "Application of Structural Equation Modeling for Estimating Airline Performance", Journal of Air Transport Management, 40, 25-33.

Joreskog, K.G. (1978), "Structural Analysis of Covariance and Correlation Matrices", Psychometrika, 43, 443-477.

Joreskog, K.G. (1982), "The LISREL Approach to Causal Model-Building in the Social Sciences”, In Wold, H. \& Wold, K.G. (Eds.), Systems under Indirect Observation, Part I (Pp. 81-100), Amsterdam: North-Holland.

Ju, Y., S.Y. Sohn (2014), "Development of A National Competitiveness Index Based on a Structural Equation Model”, Technology Analysis \& Strategic Management, 26, 65-79.

Kazazoğlu, G.N. (2014), "National Innovation System in Turkey", Turkish Public Administration Annual, 39, 49-65.

Kou, M., K. Chen, S. Wang, Y. Shao, (2016), "Measuring Efficiencies of Multi-Period and MultiPeriod and Multi-Division Systems Associated with DEA:An Application to OECD Countries' National Innovation Systems", Expert Systems With Applications, 46, 494-510.

Lee, S., Y. Nam,. S. Lee, H. Son (2015), "Determinants of ICT Innovations: A Cross-Country Empirical Study”, Technological Forecasting \& Social Change. In Press, Corrected Proof.

Liu, X., S. White (2001), “An Exploration into Regional Variation of Chinese Innovative Activity in China”, International Journal of Technology Management, 21, 2114-129.

Liu, J.S., W.M. Lu, M.H.C. Ho (2015), "National Characteristics: Innovation Systems from the Process Efficiency Perspective", R\&D Management, 45, 317-338.

Lohmoller, J.B. (1989), Latent Variable Path Modeling With Partial Least Squares, Heidelberg: Physica-Verlag. 
Lu, W.M., Q.L. Kweh, C.L. Huang (2014), "Intellectual Capital and National Innovation Systems Performance", Knowledge-Based Systems, 71, 201-210.

Lundvall, B.A. (Eds.) (1992), National Systems of Innovation - Towards a Theory of Innovation and Interactive Learning, London: Pinter Pub Ltd.

Lundvall, B. (1998), "Why Study National Systems and National Styles of Innovation?", Technology Analysis \& Strategic Management, 10, 403-422.

Mahroum, S., R. Huggins, N. Clayton, K. Pain, P. Taylor (2008), Innovation by Adoption: Measuring and Mapping Absorptive Capacity in UK Nations and Regions, London: NESTA.

Marklund, G., R. Nilsson, P. Sandgren, J. Granat Thorslund, J. Ullström (2004), “The Swedish National Innovation System 1970-(2003): A Quantitative International Benchmarking Analysis", VINNOVA Analysis VA, Stockholm (2004), 01.

Matei, M.M., A. Aldea (2012), "Ranking National Innovation Systems According to their Technical Efficiency”, Procedia - Social and Behavioral Sciences, 62, 968 - 974.

Millot, V. (2009), Trademarks As an Indicator of Product and Marketing Innovations. OECD Science, Technology and Industry Working Papers.

Mokhtarzadeh, N., H. Zarei (2014), "Investigating the Impact of National Innovation System Functions on Attracting Foreign Direct Investment in Iranian Oil Industry", International Journal Of Innovative Science, Engineering \& Technology, 1, 47-60.

Morris-King J.R., (2014), Situated Socio-Cognitive and Ecological Simulation of the Triple-Helix Theory of Regional Innovation Dynamics, PhD Dissertation, Auburn, Alabama: Graduate Faculty of Auburn University.

Nasierowski, W., F.J. Arcelus (2003), "On the Efficiency of National Innovation Systems", Socio-Economic Planning Sciences, 37, 215-234.

Nelson, R.R. (1993), National Innovation Systems: A Comparative Analysis, Oxford: Oxford University Press.

Nunnally J. C., I.H. Bernstein (1994), Psychometric Theory (3rd Ed.) New York: McGraw-Hill.

OECD (2014), Measuring the Digital Economy: A New Perspective, OECD Publishing, Paris. DOI: Http://Dx.Doi.Org/10.1787/9789264221796-En

Ollo-López, A., M.E. Aramendía-Muneta (2012), “ICT Impact on Competitiveness, Innovation and Environment", Telematics and Informatics, 29, 204-210.

Pan, T.W., S.V. Hung, W.M. Lu (2010), "DEA Performance Measurement of the National Innovation System in Asia and Europe", Asia-Pacific Journal of Operational Research, 27, 369-392.

Porter, M.E., (1990), The Competitive Advantage of Nations, Palgrave Macmillan.

Prajogo, D.I., P.K. Ahmed (2006), "Relationships between Innovation Stimulus, Innovation Capacity, and Innovation Performance", R\&D Management 36, 499-515.

Ringle, C.M., S. Wende, A. Will (2005), Smartpls 2.0, Hamburg, Germany: University of Hamburg.

Rousseau S., R. Rousseau (1997), "Data Envelopment Analysis as a Tool for Constructing Scientometric Indicators", Scientometrics, 40, 45-56. 
ÇAKIR | Kısmi En Küçük Kareler-Yapısal Eşitlik Modeli (PLS-SEM) İle AB Ülkelerinin...

Samara, E., P. Georgiadis, I. Bakouros (2012), "The Impact of Innovation Policies on the Performance of National Innovation Systems: A System Dynamics Analysis", Technovation, 32, 624-638.

Sarstedt, M., C.M. Ringle,. D. Smith, R. Reams, J.F. Hair (2014a), "Partial Least Squares Structural Equation Modeling (PLS-SEM): A Useful Tool for Family Business Researchers", Journal of Family Business Strategy, 5, 105-115.

Sarstedt, M., C.M. Ringle, J. Henseler, J.F. Hair (2014b), "On the Emancipation of PLS-SEM: A Commentary on Rigdon (2012)”, Long Range Planning, 47, 154-160.

Sohn, S.Y., D.H. Kim, S.Y. Jeon (2015), "Re-Evaluation of Global Innovation Index Based on a Structural Equation Model”. Technology Analysis \& Strategic Management, 27.

Spielkamp, A., V. Kaprin (1998), "Mapping Innovative Clusters in National Innovation Systems”, ZEW Discussion Papers No. 98-45.

Tong, L., C. Liping (2009), "Research on the Evaluation of Innovation Efficiency for China's Regional Innovation System by Utilizing DEA". International Conference on Information Management, Innovation Management and Industrial Engineering. Xian, China 26 December (2009),

Vilaseca, J., J. Torrent, J. Lladós, L. Garay (2006), El Impacto De Las TIC En La Empresa Turística: El Caso De Cataluña. UOC, Working Paper Series, WP06-003.

Wang, E., W. Huang (2007), "Relative Efficiency of R\&D Activities: A Cross-Country Study Accounting for Environmental Factors in the DEA Approach", Research Policy, 36, 260273.

Wiseman A.W., E. Anderson (2012), "ICT-Integrated Education and National Innovation Systems in the Gulf Cooperation Council (GCC) Countries", Computers \& Education, 59, 607-618.

Wold, H. (1982), Soft Modeling: The Basic Design and Some Extensions, In: Joreskog, K.G., Wold, H. (ed.), Systems under Indirect Observations, Part II, Amsterdam: North-Holland, $1-54$.

World Economic Forum (WEF) (2015), The Global Competitiveness Report (2014)-(2015), Geneva.

Yam, R.C.M., W. Lo, P.Y.T. Esther, K.W.L. Antonio (2011), “Analysis of Sources of Innovation, Technological Innovation Capabilities, and Performance: An Empirical Study of Hong Kong Manufacturing Industries”, Research Policy, 40, 391-402.

Yoon, Y., D. Gürsoy, J.S. Chen (2001), "Validating a Tourism Development Theory with Structural Equation Modeling", Tourism Management, 22, 363-372.

Zhang, J. (2013), "International Comparison of National Innovation System Efficiency", AsiaPacific Tech Monitor, 30, 23-29. 